\title{
Pengaruh Penerimaan Layanan Kesehatan Dari Petugas Kesehatan terhadap Pemanfaatan Tenaga Kesehatan Puskesmas Cibadak - Lebak
}

\author{
Kadar Kuswandi*, Omo Sutomo**
}

\begin{abstract}
Abstrak
Masih banyak ditemukannya masyarakat yang memanfaatkan jasa bukan tenaga kesehatan dalam menanggulangi masalah kesehatan yang dialaminya, sehingga dapat berdampak terhadap tingginya angka kesakitan dan kematian yang terjadi di masyarakat, yang kesemuanya itu dapat berakibat pada rendahnya derajat kesehatan masyarakat yang bersangkutan. Keadaan tersebut dapat diakibatkan karena pengalaman yang kurang menyenangkan/kurang baik yang diterima oleh masyarakat sebagai pengguna jasa layanan kesehatan dari petugas kesehatan yang ada. Disain penelitian yang digunakan berupa penelitian analitik untuk melihat hubungan antar variable dengan pendekatan cross sectional. Populasi penelitian ini seluruh masyarakat di wilayah kerja Puskesmas Cibadak yang pernah menerima pelayanan kesehatan dari petugas kesehatan puskesmas. Sampel berjumlah 100 orang yang ditentukan dengan menggunakan tehnik non random sampling (pusposif). Data dikumpulkan dengan menggunakan kuesioner. Hasil penelitian menunjukkan bahwa, sebagian besar $(65,0 \%)$ memiliki pengalaman yang kurang baik terhadap pemberi layanan kesehatan, dan lebih dari sebagian $(51,0 \%)$ merencanakan untuk tidak memanfaatkan kembali tenaga/fasilitas kesehatan yang sama pada saat mereka membutuhkan bantuan tenaga kesehatan. Responden yang berpendidikan rendah lebih banyak berencana untuk tidak memanfaatkan kembali tenaga kesehatan yang sama $(\mathrm{p}=0,044)$, dan yang memiliki pengalaman kurang baik lebih banyak yang berencana untuk tidak memanfaatkan kembali tenaga kesehatan yang sama $(p=0,000)$. Sedang jenis kelamin tidak memiliki hubungan bermakna dengan pemanfaatan kembali tenaga/fasilitas kesehatan yang sama $(\mathrm{p}=0,319)$. Dengan masih banyaknya ditemukan pengguna jasa layanan kesehatan yang merasa tidak puas (memiliki pengalaman kurang baik) terhadap petugas/fasilitas kesehatan yang ada, maka sebaiknya perlu dilakukan pelatihan cara pemberian layanan kesehatan yang baik; dan untuk terus dihimbau bagi tenaga kesehatan untuk dapat memberikan layanan yang baik.
\end{abstract}




\section{Pendahuluan}

Pemanfaatan tenaga kesehatan
oleh masyarakat di masyarakat dalam
penanggulangan masalah kesehatan
merupakan hal penting yang harus ada
dalam masayarakat. Pemanfaatan tenaga
kesehatan yang tidak optimal dapat
berakibat terhadap memanjangnya masa
sakit bahkan dapat menimbulkan akibat
fatal berupa kematian.

Di masyarakat, keyakinan yang dianut sangat menentukan bagaimana mereka harus bertindak terhadap penyelesaian masalah kesehatan. Syafrudin dkk (2009) menyatakan bahwa perilaku kesehatan dan pemilihan pertolongan tergantung dari keyakinan masyarakat terhadap penyebab terjadinya penyakit. Disamping itu, selain sisi masyarakat sebagai pengguna layanan kesehatan, bahwa tenaga kesehatan di puskesmas juga tidak bisa diabaikan dalam memberikan layanan.

Perilaku petugas kesehatan dalam memberikan layanan kesehatan dapat berpengaruh terhadap perilaku masyarakat dalam pemanfaatan layanan yang akan diberikan oleh petugas. L Green dalam
Notoatmodjo (2003) menyatakan bahwa salah satu factor yang dapat berpengaruh untuk memperkuat perilaku kesehatan masyarakat adalah perilaku atau sikap petugas kesehatan.

Dari hasil survey pendahuluan terhadap 10 (sepuluh) orang masyarakat yang ada di wilayah kerja puskesmas Cibadak didapatkan bahwa sekitar $40 \%$ dari mereka menyatakan bahwa petugas kesehatan di wilayahnya sangat dibutuhkan, tetapi mereka juga merasa bahwa perilaku dan sikap petugas seringkali tidak menyenangkan, sehingga membuat mereka malas atau enggan datang kembali ke puskesmas untuk berobat.

Tujuan dari penelitian ini adalah teridentifikasinya pengaruh jenis kelamin, pendidikan formal terakhir, dan pengalaman masyarakat saat menerima layanan kesehatan pada masa lalu terhadap pemanfaatan layanan kesehatan yang diberikan oleh tenaga kesehatan pada masa berikutnya.

Hipotesis yang dikemukakan dalam penelitian ini adalah (1) masyarakat dengan jenis kelamin laki-laki akan 
memiliki kecenderungan lebih besar untuk dapat memanfaatkan kembali tenga kesehatan di masa mendatang dibandingkan dengan masyarakat yang berjenis kelamin perempuan; (2) masyarakat dengan pendidikan formal terakhir SLTA ke atas, akan memiliki kecenderungan lebih besar untuk dapat memanfaatkan kembali tenaga kesehatan di masa mendatang dibandingkan dengan masyarakat yang berpendidikan SLTP kebawah; (3) masyarakat yang memiliki pengalaman baik saat menerima layanan kesehatan dari petugas kesehatan akan lebih bisa memanfaatkan layanan tenaga kesehatan dimasa mendatang dibandingkan dengan masyarakat yang memiliki pengalaman kurang baik dari petugas kesehatan saat menerima layanan kesehatan.

\section{Hasil Penelitian}

Setelah data diolah dengan menggunakan perangkat lunak, maka selanjutnya hasil penelitian disajikan dalam bentuk table. Hasil penelitian ini terbagi menjadi hasil analisis univariat dan hasil analisis bivariat.

Tabel 1

Distribusi Responden Berdasarkan Pemanfaatan Kembali Tenaga Kesehatan Di Wilayah Kerja Puskesmas Cibadak

\begin{tabular}{ccc}
\multicolumn{3}{c}{ Tahun 2013 } \\
\hline $\begin{array}{c}\text { Pemanfaatan } \\
\text { Kembali }\end{array}$ & Frekuensi & Persen \\
\hline
\end{tabular}

\begin{tabular}{ccc}
\hline Tidak & 51 & 51,0 \\
Ya & 49 & 49,0 \\
\hline Jumlah & 100 & 100,0 \\
\hline
\end{tabular}

Tabel 1 menunjukkan bahwa lebih dari sebagian $(51,0 \%)$ masyarakat yang pernah mendapat pelayanan kesehatan dari tenaga kesehatan di wilayah kerja Puskesmas Cibadak, memiliki keinginan untuk tidak memanfaatkan kembali tenaga kesehatan yang sama pada saat mereka berobat ulang.

Tabel 2

Distribusi Responden Berdasarkan Jenis

Kelamin

Di Wilayah Kerja Puskesmas Cibadak

Tahun 2013

\begin{tabular}{ccc}
\hline Jenis Kelamin & Frekuensi & Persen \\
\hline Laki-Laki & 49 & 49,0 \\
Perempuan & 51 & 51,0 \\
\hline Jumlah & 100 & 100,0 \\
\hline
\end{tabular}

Tabel 2 menunjukkan bahwa lebih dari sebagian $(51,0 \%)$ masyarakat yang terandom menjadi responden dan pernah menerima pelayanan kesehatan adalah berjenis kelamin perempuan.

Tabel 3

Distribusi Responden Berdasarkan Tingkat Pendidikan Formal Terakhir Di Wilayah Kerja Puskesmas Cibadak Tahun 2013 


\begin{tabular}{ccc}
\hline $\begin{array}{c}\text { Tingkat } \\
\text { Pendidikan }\end{array}$ & Frekuensi & Persen \\
\hline $\begin{array}{c}\text { Rendah }(\leq \\
\text { SLTP) }\end{array}$ & 77 & 77,0 \\
Tinggi $(>$ & 23 & 23,0 \\
SLTP) & & \\
\hline Jumlah & 100 & 100,0 \\
\hline
\end{tabular}

Tabel 4.3 menunjukkan bahwa sebagian besar $(77,0 \%)$ masyarakat yang terandom menjadi responden dan pernah menerima pelayanan kesehatan adalah yang berpendidikan SLTP kebawah.

Tabel 4

Distribusi Responden Berdasarkan Pengalaman

Menerima Pelayanan Petugas Kesehatan

Di Wilayah Kerja Puskesmas Cibadak

\begin{tabular}{ccc}
\multicolumn{3}{c}{ Tahun 2013} \\
\hline Pengalaman & Frekuensi & Persen \\
& & \\
\hline Kurang Baik & 65 & 65,0
\end{tabular}

\begin{tabular}{ccc} 
Baik & 35 & 35,0 \\
\hline Jumlah & 100 & 100,0 \\
\hline
\end{tabular}

Tabel 4 menunjukkan bahwa sebagian besar $(65,0 \%)$ masyarakat yang pernah menerima layanan dari petugas kesehatan yang ada di Puskesmas Cibadak mempersepsikan bahwa mereka memiliki pengalaman/penilaian yang kurang baik terhadap pelayanan yang pernah mereka terima.

\begin{tabular}{|c|c|c|c|c|}
\hline \multirow{2}{*}{\multicolumn{5}{|c|}{$\begin{array}{c}\text { Tabel } 5 \\
\text { Distribusi Responden Berdasarkan Jenis } \\
\text { Kelamin } \\
\text { Dan Keinginan Memanfaatkan Petugas } \\
\text { Kesehatan } \\
\text { Di Wilayah Kerja Puskesmas Cibadak - Lebak } \\
\text { Tahun } 2013\end{array}$}} \\
\hline & & & & \\
\hline \multirow[t]{2}{*}{$\begin{array}{c}\text { Jenis } \\
\text { Kelamin }\end{array}$} & \multicolumn{2}{|c|}{$\begin{array}{l}\text { Pemanfaatan } \\
\text { Kembali }\end{array}$} & \multirow[t]{2}{*}{ Jumlah } & \multirow[t]{2}{*}{$\begin{array}{l}\text { Nila } \\
\text { i p }\end{array}$} \\
\hline & Tidak & $\mathrm{Ya}$ & & \\
\hline $\begin{array}{l}\text { Laki- } \\
\text { Laki }\end{array}$ & $\begin{array}{c}22 \\
(44,9 \\
\%)\end{array}$ & $\begin{array}{c}27 \\
(55,1 \\
\%)\end{array}$ & $\begin{array}{c}49 \\
(100,0 \\
\%)\end{array}$ & 031 \\
\hline Perempu & 29 & 22 & 51 & 9 \\
\hline
\end{tabular}

\begin{tabular}{cccc}
\hline an & $\begin{array}{c}(56,9 \\
\%)\end{array}$ & $\begin{array}{c}(43,1 \\
\%)\end{array}$ & $\begin{array}{c}(100,0 \\
\%)\end{array}$ \\
\hline Jumlah & $\begin{array}{c}51 \\
(51,0 \\
\%)\end{array}$ & $\begin{array}{c}(49,0 \\
\%)\end{array}$ & $\begin{array}{c}(100,0 \\
\%)\end{array}$ \\
& $\begin{array}{c}(100 \\
\end{array}$
\end{tabular}

Secara deskriptif table 5 menunjukkan bahwa kelompok responden dengan jenis kelamin perempuan lebih banyak $(56,9 \%)$ yang menyatakatan untuk tidak memanfaatkan kembali tenaga kesehatan yang pernah memberikan layanan terhadap dirinya; dibandingkan dengan responden yang berjenis kelamin lakilaki, hanya $44,9 \%$ yang menyatakan untuk tidak memanfaatkan kembali tenaga kesehatan yang sama.

Akan tetapi secara bivariat diperoleh nilai $\mathrm{p}$ sebesar $0,319(\mathrm{p}>\alpha)$, yang berarti bahwa jenis kelamin tidak memiliki hubungan bermakna terhadap pemanfaatan kembali pada tenaga kesehatan yang sama.

Tabel 6

Distribusi Responden Berdasarkan Tingkat Pendidikan Dan Pemanfaatan Petugas Kesehatan Di Wil. Kerja Puskesmas Cibadak - Lebak Tahun 2013

\begin{tabular}{|c|c|c|c|c|c|}
\hline \multirow[t]{2}{*}{$\begin{array}{c}\text { Tk. } \\
\text { Pnddkn }\end{array}$} & \multicolumn{2}{|c|}{$\begin{array}{c}\text { Pemanfatan } \\
\text { Kembali }\end{array}$} & \multirow[t]{2}{*}{ Jumlah } & \multirow[t]{2}{*}{$\begin{array}{l}\text { Nila } \\
\text { i p }\end{array}$} & \multirow[t]{2}{*}{$\begin{array}{c}\text { CI } \\
(95 \%)\end{array}$} \\
\hline & Tdk & Ya & & & \\
\hline $\begin{array}{c}\text { Rendah } \\
(<\end{array}$ & $\begin{array}{c}44 \\
(57.1\end{array}$ & $\begin{array}{c}33 \\
(42.9\end{array}$ & $\begin{array}{c}77 \\
(100,0\end{array}$ & & \\
\hline \multirow[t]{3}{*}{ SLTP) } & $\%)$ & $\%)$ & $\%)$ & & 3,048 \\
\hline & & & & 0,04 & $(1,125$ \\
\hline & & & & 4 & $\overline{8}, 254)$ \\
\hline $\begin{array}{l}\text { Tinggi } \\
\text { (>SLT }\end{array}$ & $\begin{array}{c}7 \\
(30,4\end{array}$ & $\begin{array}{c}16 \\
(69,6\end{array}$ & $\begin{array}{c}23 \\
(100,0\end{array}$ & & \\
\hline P) & $\%)$ & $\%)$ & $\%)$ & & \\
\hline
\end{tabular}




\begin{tabular}{cccc}
\hline Jumlah & 51 & 49 & 100 \\
& $(51,0$ & $(49,0$ & $(100,0$ \\
& $\%)$ & $\%)$ & $\%)$ \\
\hline
\end{tabular}

Secara deskriptif table 6 menunjukkan bahwa kelompok responden dengan pendidikan rendah (SLTP kebawah) lebih banyak $(57,1 \%)$ yang menyatakatan untuk tidak memanfaatkan kembali tenaga kesehatan yang pernah memberikan layanan terhadap dirinya;

dibandingkan dengan responden yang berpendidikan tinggi (SLTA keatas), hanya $30,4 \%$ yang menyatakan untuk tidak memanfaatkan kembali tenaga kesehatan yang sama. Secara bivariat diperoleh nilai $\mathrm{p}$ sebesar $0,044(\mathrm{p}<\alpha)$, yang berarti bahwa tingkat pendidikan formal responden memiliki hubungan bermakna dengan pemanfaatan kembali pada tenaga kesehatan yang sama. Dengan nilai OR sebesar 3,048 yang berarti bahwa responden yang memiliki pendidikan formal SLTP kebawah berisiko untuk tidak memanfaatkan kembali tenaga kesehatan yang sama apabila mereka mengalami perlakuan atau pengalaman yang kurang baik dari petugas yang pernah memberikan layanan pada dirinya.

Tabel 7

Distribusi Responden Berdasarkan Pengalaman Menerima Layanan Dan Keinginan Memanfaatkan Petugas Kesehatan

Jurnal Medikes,Volume I, edisi I, April 2014
Di Wilayah Kerja Puskesmas Cibadak - Lebak

\begin{tabular}{|c|c|c|c|c|c|}
\hline \multirow{3}{*}{ Pengalaman } & & & & \multirow{3}{*}{$\begin{array}{c}\mathrm{Ni} \\
\text { lai } \\
\mathrm{p}\end{array}$} & \\
\hline & \multicolumn{2}{|c|}{$\begin{array}{l}\text { Pemanfaatan } \\
\text { Kembali }\end{array}$} & \multirow[t]{2}{*}{$\mathrm{Jml}$} & & \multirow[t]{2}{*}{$\begin{array}{c}\mathrm{CI} \\
(95 \%)\end{array}$} \\
\hline & Tdk & $\mathrm{Ya}$ & & & \\
\hline Kurang & 51 & 14 & 65 & & 0,215 \\
\hline \multirow[t]{3}{*}{ Baik } & $(78,5 \%$ & $(21,5 \%)$ & $(100,0$ & & $(0,13$ \\
\hline & ) & & $\%)$ & 0 , & $5-$ \\
\hline & & & 35 & 0 & ) \\
\hline \multirow[t]{5}{*}{ Baik } & 0 & $(100,0 \%$ & $(100,0$ & & Ket: \\
\hline & $(0,0 \%)$ & ) & $\%)$ & & For \\
\hline & & & & & cohort \\
\hline & & & & & pema \\
\hline & & & & & matal \\
\hline \multirow[t]{3}{*}{ Jumlah } & 51 & 49 & 100 & & \\
\hline & $(51,0 \%)$ & $(49,0 \%)$ & $(100,0$ & & \\
\hline & & & $\%)$ & & \\
\hline
\end{tabular}

Secara deskriptif table 7 menunjukkan bahwa kelompok responden yang memiliki pengalaman kurang baik saat menerima layanan dari petugas kesehatan, lebih banyak $(78,5 \%)$ yang menyatakatan untuk tidak memanfaatkan kembali tenaga kesehatan yang pernah memberikan layanan terhadap dirinya; dibandingkan dengan responden yang memiliki pengalaman baik saat menerima layanan kesehatan, tidak terdapat $(0,0 \%)$ yang menyatakan untuk tidak memanfaatkan kembali tenaga kesehatan yang sama. Secara bivariat diperoleh nilai $\mathrm{p}$ sebesar $0,000(\mathrm{p}<\alpha)$, yang berarti bahwa pengalaman terdahulu dari responden saat menerima layanan dari petugas kesehatan, memiliki hubungan bermakna dengan pemanfaatan kembali pada tenaga kesehatan yang sama. Dengan nilai OR 
sebesar 0,215 yang berarti bahwa responden memiliki pengalaman kurang baik saat menerima layanan dari petugas kesehatan dapat mencegah (menghambat) kembalinya responden tersebut untuk memanfaatkan kembali tenaga kesehatan yang sama.

\section{Pembahasan}

Hubungan Tingkat Pendidikan Formal dengan Pemanfaatan Kembali Petugas kesehatan

Hasil analisis secara deskriptif menunjukkan bahwa kelompok responden dengan jenis kelamin perempuan lebih banyak $(56,9 \%)$ yang menyatakatan untuk tidak memanfaatkan kembali tenaga kesehatan yang pernah memberikan layanan terhadap dirinya; dibandingkan dengan responden yang berjenis kelamin laki-laki, hanya $44,9 \%$ yang menyatakan untuk tidak memanfaatkan kembali tenaga kesehatan yang sama. Akan tetapi secara bivariat diperoleh nilai $\mathrm{p}$ sebesar $0,319(\mathrm{p}$ $>\alpha$ ), yang berarti bahwa jenis kelamin tidak memiliki hubungan bermakna terhadap pemanfaatan kembali pada tenaga kesehatan yang sama.

Hasil penelitian ini menunjukkan bahwa responden laki-laki maupun wanita tidak memiliki perbedaan yang signifikan dalam menggunakan tenaga/fasilitas kesehatan yang sama dimasa yang akan dating, walaupun mereka pernah mengalami hal yang kurang menyenangkan dari petugas/fasilitas kesehatan yang pernah mereka gunakan dalam mengatasi masalah kesehatannya. Robbins (2003) menyatakan bahwa tidak ada perbedaan yang konsisten antara pria dan wanita dalam kemampuan memecahkan masalah, keterampilan analisis, dorongan kompetetif, motivasi, sosiabilitas, atau kemampuan belajar.

Dari pernyataan tersebut menjelaskan bahwa responden (dilihat berdasarkan jenis kelamin) memiliki kebutuhan dan kemampuan yang sama, sehingga pada saat mereka memiliki kesempatan/waktu untuk melakukan perilaku tertentu, maka perilaku itu akan dapat dilakukan baik oleh responden yang berjenis kelamin laki-laki maupun perempuan. Begitu pula perilaku mereka dalam memanfaatkan petugas/fasilitas kesehatan yang ada di sekitar mereka; dilihat berdasarkan jenis kelamin, bahwa mereka akan memanfaatkan tenaga/fasilitas kesehatan yang ada secara sama. 
Pada bagian lain Robbins (2003) menyatakan bahwa secara psikologis bahwa wanita lebih bersedia untuk mematuhi wewenang dan pria lebih agresif dan lebih besar kemungkinannya daripada wanita dalam memiliki penghargaan (ekspektasi) untuk sukses, tetapi perbedaan ini kecil adanya. Dengan kata lain bahwa perbedaan itu tidak cukup kuat untuk menjelaskan bahwa antara lakilaki dan wanita memiliki perbedaan secara psikologis. Oleh karena itu, perbedaan pemanfaatan tenaga/fasilitas kesehatan kembali dimasa yang akan dating bukan dipengaruhi oleh factor perbedaan jenis kelamin, melainkan lebih kepada factor lain yang lebih bias dirasakan oleh responden sebagai pengguna jasa layanan kesehatan; factor tersebut antara lain pengalaman nyata pada saat mereka menerima layanan kesehatan.

Pengalaman nyata yang dialami oleh responden akan lebih membekas dalam benak mereka, sehingga akan sangat menentukan mereka dalam menggunakan jasa petugas/fasilitas kesehatan yang sama di masa yang akan dating, apabila mereka mengalami masalah kesehatan dan mencari bantuan untuk mengatasi masalah kesehatan yang sedang dihadapinya. Ahmadi (1998) menyatakan bahwa individu dapat menyadari atau memahami sesuatu apabila individu tersebut menangkap adanya objek yang diamati, memiliki alat indra yang baik, dan adanya perhatian. Sedangkan Notoatmodjo menyatakan bahwa dengan pendidikan orang akan mendapatkan pengetahun dan dari pengetahuan ini perilaku seseorang dapat berubah; dari dua pernyataan itu mengartikan bahwa perilaku responden baik laki-laki maupun perempuan, akan berubah apabila mereka telah memperoleh pengalaman yang langsung dialaminya dan mereka memiliki perhatian terhadap pengalaman tersebut, sehingga pengalaman itu dijadikan sebagai hasil belajar nyata yang berdampak terhadap meningkatnya kesan yang tertinggal dalam benak mereka, sehingga perilaku berikutnya dapat berubah karena adanya kesan/ pengetahuan dari pengalaman yang mereka alami.

Hubungan Tingkat Pendidikan Formal dengan Pemanfaatan Kembali Petugas kesehatan

Hasil analisis secara deskriptif menunjukkan bahwa responden yang pernah menerima layanan kesehatan dari 
petugas kesehatan dan berpendidikan rendah (SLTP kebawah) lebih banyak $(57,1 \%)$ yang menyatakatan untuk tidak memanfaatkan kembali tenaga kesehatan yang pernah memberikan layanan terhadap dirinya; dibandingkan dengan responden yang berpendidikan tinggi (SLTA keatas), hanya $30,4 \%$ yang menyatakan untuk tidak memanfaatkan kembali tenaga kesehatan yang sama.

Dari hasil analisis yang dilihat secara angka proporsi tampak bahwa tingkat pendidikan memiliki kecenderungan untuk dapat mempengaruhi perilaku dalam pemanfaatan tenaga kesehatan yang sama kembali pada saat responden membutuhkan bantuan/layanan kesehatan. Semakin pendidikan responden rendah maka semakin banyak responden yang menyatakan untuk tidak memanfaatkan kembali tenaga kesehatan yang sama pada saat mereka membutuhkan layanan kesehatan. Hal itu dapat disebabkan karena pendidikan seseorang mempengaruhi pengetahuannya dan berdampak pada perilakunya. Notoatmodjo (1999) menyatakan
bahwa dengan pendidikan orang akan mendapatkan pengetahun dan dari pengetahuan ini perilaku seseorang dapat berubah. Jadi untuk mengubah perilaku dibutuhkan adanya informasi yang diperoleh orang tersebut yang dapat mempengaruhi pengetahuannya. Oleh karena itu hasil penelitian ini menunjukkan bahwa pendidikan responden memungkinkan untuk berpengaruh terhadap perilakunya dalam pemanfaatan kembali pada petugas kesehatan yang sama, saat responden tersebut membutuhkan layanan kesehatan.

Kenyataan itu ditunjang oleh hasil yang diperoleh secara bivariat, yang menunjukkan bahwa nilap $\mathrm{p}$ yang diperoleh lebih kecil $(0,044)$ dari alpha yang digunakan (0,05); yang secara statistic dapat diartikan bahwa tingkat pendidikan responden berpengaruh terhadap pemanfaatan kembali pada tenaga kesehatan yang sama, saat responden tersebut membutuhkan layanan kesehatan. Dengan kata lain bahwa responden yang pendidikannya SLTP kebawah berpotensi lebih besar untuk tidak memanfaatkan kembali jasa tenaga kesehatan yang sama, saat mereka membutuhkan layanan kesehatan, 
sehingga memungkinkan mereka dapat beralih menggunakan jasa tenaga lain (termasuk tidak menggunakan tenaga kesehatan). Hal itu ditunjukkan dengan nilai OR yang diperoleh sebesar 3,048 yang berarti bahwa responden yang pendidikannya SLTP kebawah berisiko tiga kali lebih besar untu tidak memanfaatkan kembali jasa tenaga/tempat layanan kesehatan yang sama, pada saat merekan membutuhkan layanan kesehatan; dibandingkan dengan responden yang berpendidikan SLTA.

Melihat kenyataan seperti itu, maka dibutuhkan upaya pencegahan terjadinya keadaan/perasaan "kapok" dari responden sebagai pengguana jasa layanan kesehatan untuk memanfaatkan tenaga/fasilitas kesehatan yang sama, pada saat responden membutuhkan layanan kesehatan, seperti adanya upaya perbaikan layanan kesehatan yang diberikan baik berupa perbaikan dalam sarana dan prasarana, maupun yang berkaitan dengan sikap dan perilaku petugas kesehatan itu sendiri.. Melalui upaya-upaya tersebut diharapkan responden dan keluarganya dapat tergerak untuk tetap memilih tenaga/fasilitas kesehatan yang sama yang ada di lingkungan mereka, sehingga tingkat kesehatan mereka tetap terjaga, dan tidak menggunakan jasa di luar tenaga/fasilitas kesehatan. Notoatmodjo (2003) menyatakan bahwa pendidikan kesehatan yang dilakukan melalui pemberian contoh nyata berupa perilaku atau sikap dari petugas kesehatan adalah penting untuk menunjang program kesehatan lainnya, karena melalui pendidikan kesehatan seperti itu, masyarakat dapat melihat secara langsung sikap dan perilaku yang menunjang kesehatan, sehingga pengetahuan masyarakat akan meningkat, yang berdampak pada perilaku berupa pemanfaatan jasa layanan kesehatan bila mereka membutuhkan layanan kesehatan.

Disisi lain Wiknjosastro (1999) menyatakan bahwa angka kesakitan dan kematian ibu dan anak dapat ditekan dengan cepat melalui peningkatan kesejahteraan masyarakat/peningkatan taraf hidup masyarakat. Pendidikan dan pengetahuan merupakan bagian yang penting untuk meningkatkan taraf hidup/kesejahteraan masyarakat. Oleh karena itu, tenaga kesehatan (khususnya bidan dan perawat) sebagai ujung tombak 
pelayanan kesehatan di masyarakat harus dapat melaksanakan pendidikan kesehatan dengan baik kepada masyarakat dan keluarganya, sehingga mereka memahami dan mau memanfaatkan petugas/fasilitas kesehatan pada saat mereka membutuhkan bantuan untuk mengatasi masalah kesehatannya. Bidan dan perawat di desa harus dekat dengan masyarakat. Oleh karena itu setiap bidan dan perawat di desa harus mau dan mampu tinggal di tengah-tengah masyarakat binaannya, sekaligus sebagai pengguna jasanya, sehingga bila masyarakat membutuhkan pertolongan, mereka akan mudah untuk menjangkaunya.

\section{Hubungan Pengalaman Menerima Layanan Kesehatan Dimasa Lalu dengan Kemungkinan Pemanfaatan Kembali pada Petugas/Fasilitas Kesehatan yang Sama}

Dari hasil analisis secara deskriptif menunjukkan bahwa kelompok responden yang memiliki pengalaman kurang baik saat menerima layanan dari petugas kesehatan dimasa lalu, lebih banyak $(78,5 \%)$ yang menyatakatan untuk tidak memanfaatkan kembali tenaga kesehatan yang pernah memberikan layanan terhadap dirinya; dibandingkan dengan responden yang memiliki pengalaman baik saat menerima layanan kesehatan, tidak terdapat $(0,0 \%)$ yang menyatakan untuk tidak memanfaatkan kembali tenaga kesehatan yang sama.

Hal itu mengisyaratkan bahwa pengalaman masa lalu dari seseorang dapat berpotensi untuk berpengaruh terhadap perilakunya di masa sekarang dan akan dating. Seseorang atau individu yang mengalami atau memiliki pengalaman kurang baik terhadap sesuatu hal dimasa yang lalu, biasanya akan selalu teringat atau tergambar dalam benaknya, sehingga pada saat individu tersebut menemui masalah yang sama di masa mendatang, maka individu tersebut akan berusaha untuk menghindari cara-cara yang pernah dilakukannya, yang berdampak pada dilakukannya perilaku baru untuk mengatasi masalah yang sama.

Ahmadi (1998) menyatakan bahwa individu dapat menyadari atau memahami sesuatu apabila individu tersebut menangkap adanya objek yang diamati, memiliki alat indra yang baik, dan adanya perhatian. Pernyataan itu menggambarkan bahwa pengalaman nyata yang dialami 
oleh responden pada saat menerima layanan kesehatan dari petugas/fasilitas kesehatan akan masuk ke dalam benak responden (sebagai pengguna/penerima layanan jasa kesehatan) melalui alat pengindraan (pendengaran dan penglihatan yang baik), dimana pada saat responden merasakan secara langsung tentang sikap dan perilaku petugas kesehatan dan responden yang bersangkutan memiliki perhatian terhadap apa yang sudah dialaminya tersebut, sehingga gambaran pengalamannya tersimpan dalam benak responden, yang kemudian responden berperilaku sesuai dengan pengalaman yang diterimanya itu; bila pengalamannya baik, maka kemungkinan responden akan menggunakan kembali jasa tenaga kesehatan yang pernah memberikan/melayaninya. Akan tetapi bila pengalamannya kurang baik, maka responden tersebut memungkinkan untuk tidak menggunakan kembali jasa layanan dari tenaga kesehatan yang sama.

Keadaan tersebut ditunjang oleh hasil secara bivariat yang memperoleh nilai $p$ sebesar $0,000(p<\alpha)$, yang berarti bahwa pengalaman terdahulu dari responden saat menerima layanan dari petugas kesehatan, memiliki hubungan bermakna dengan pemanfaatan kembali pada tenaga kesehatan yang sama. Dengan nilai OR sebesar 0,215 yang berarti bahwa responden memiliki pengalaman kurang baik saat menerima layanan dari petugas kesehatan dapat mencegah (menghambat) kembalinya responden tersebut untuk memanfaatkan kembali tenaga kesehatan yang sama. Atau dengan kata lain bahwa responden yang memiliki pengalaman kurang baik pada petugas kesehatan dimasa lalu saat mereka menerima layanan, berisiko 4,6 (hampir lima kali) lebih besar untuk tidak memanfaatkan kembali jasa petugas/fasilitas kesehatan yang sama pada saat mereka mengatasi masalah kesehatannya di masa yang akan dating, bila dibandingkan dengan responden yang memiliki pengalaman baik dengan petugas kesehatan.

Notoatmodjo (2003) menyatakan bahwa pengalaman individu merupakan suatu hal yang sangat berarti dalam peningkatan kesehatan masyarakat; melalui pengalaman nyata, individu dapat memperoleh pembelajaran langsung yang membekas, sehingga sangat berpotensi mempengaruhi perilakunya dalam kesehatan masyarakat. Artinya, seorang 
individu yang apabila diberikan pengalaman yang baik dalam perilaku kesehatan secara nyata, maka individu tersebut akan lebih mudah untuk dapat menerima dan mengaplikasikannya dalam kehidupan sehari-hari, bila dibandingkan dengan hanya diberi penyuluhan. Begitu pula apabila pengalaman nyata tersebut berupa pengalaman yang kurang baik dalam menerima perlakuan atau layanan dari petugas/fasilitas kesehatan saat individu tersebut dating ke petugas/fasilitas kesehatan untuk mengatasi masalah kesehatannya, maka pengalaman tersebut juga akan selalu tergambar dalam ingatannya, dan memungkinkan individu tersebut untuk tidak menggunakan jasa petugas/fasilitas kesehatan yang sama pada saat mereka menghadapi/mengatasi masalah kesehatannya.

Oleh karena itu, petugas kesehatan sebagai ujung tombak di masyarakat dalam meningkatkan derajat kesehatan secara umum harus benar-benar memperhatikan kebutuhan pengguna jasa layanan kesehatan, dan bukan berorientasi pada kebutuhan diri sendiri. La Monica (1998) menyatakan bahwa klien (sebagai penerima jasa layanan) harus menjadi focus utama dalam pelayanan kesehatan, sehingga para personil pelayan kesehatan idealnya harus memiliki kemampuan optimal dalam memberikan layanan, termasuk di dalamnya memperhatikan kebutuhan-kebutuhan klien yang berkaitan dengan kesehatan.

Pada bagian lain La Monica (1998) menyatakan bahwa bias jadi masyarakat mampu memanfaatkan petugas/fasilitas kesehatan, tetapi mereka tidak mau untuk memanfaatkannya. Keadaan tersebut dapat disebabkan karena adanya pengalaman yang kurang baik dari mereka para pengguna jasa pelayanan kesehatan, sehingga mereka enggan untuk menggunakan kembali tenaga/fasilitas kesehatan yang sama pada saat mereka mengatasi masalah kesehatannya.

Mengingat hal tersebut, maka petugas kesehatan perlu kiranya dapat memainkan perannya di masyarakat sesuai dengan harapan yang ada di masyarakat yang bersangkutan, seperti dapat memberikan pelayanan dengan cepat, ramah, memiliki sikap dan kemampuan yang baik, dan sebagainya. Karena pada dasarnya setiap individu pada saat mereka dating ke petugas kesehatan, mereka ingin mendapatkan pelayanan yang baik dan 
dihargai oleh petugas sebagai pemberi layanan.

Ilyas (2003) menyatakan bahwa motivasi individu untuk berperilaku baik dapat didorong dengan adanya pencapaian kesuksesan, dan penghargaan diri. Hal itu dapat diartikan bahwa melalui keberhasilan pelayanan yang diberikan oleh pemberi layanan dan juga dirasakan oleh penerima layanan, maka hal tersebut dapat mendorong pengguna layanan untuk berperilaku dating kembali ke petugas yang sama pada saat mereka membutuhkan bantuan tenaga kesehatan.

Disamping itu, penghargaan diri yang diberikan oleh tenaga kesehatan pada saat memberikan layanan kepada masyarakat sebagai penerima jasa layanan, akan membuat masyarakat merasa dihargai (bermartabat), sehingga muncul rasa percaya diri bagi masyarakat untuk tetap menggunakan jasa layanan kesehatan dari petugas kesehatan yang besangkutan.

\section{Daftar Pustaka}

Ahmadi, Abu (1998). Psikologi Umum. Cetakan kedua. Jakarta: Rineka Cipta.
Dinkes Provinsi DI Yogyakarta. 2012. Berita dan Artikel Dinas Kesehatan Jogjakarta - Survey Kepuasan Pelanggan Dinkes Provinsi Jogjakarta. Edisi 2012. Jogjakarta: Dinkes Prov. DIY

Direktur Jenderal Bina Gizi Kesehatan Ibu dan Anak Kemenkes RI Slamet Riyadi Yuwono dalam Andalas. 2012. Derajat Kesehatan Masyarakat Indikator Negara Maju. Edisi 08 Desember.

Ilyas, Yaslis. 2003. Kiat Sukses Manajemen Tim Kerja. Jakarta: PT Gramedia Pustaka Utama.

Ka.Dinkes Lebak dalam Antara. 2011. Pemkab Lebak Targetkan Angka Kematian Ibu Turun. Edisi Rabu 20 Juli.

Kemenkes RI - Direktorat Jenderal Bina Gizi \& KIA. 2011. Pencapaian Target MDGs Di Provinsi Binaan Direktorat Jenderal Bina Gizi \& KIA (Jawa Tengah, Banten \& Papua Barat) Tahun 2010. Jakarta: Direktorat Jenderal Bina Gizi \& KIA.

La Monica, Elaine L. 1998. Cetakan I. Alih bahasa: Susi Purwoko (ed). Kepemimpinan dan Manajemen Keperawatan - Pendekanan Berdasarkan Pengalaman. Jakarta: EGC

Notoatmodjo, Soekidjo. 1993. Pengantar Pendidikan Kesehatan dan Ilmu Perilaku Kesehatan - Bab XI p.133. Perilaku Pencarian Pelayanan kesehatan. Jogjakarta: Andi Offset 
Notoatmodjo, Soekidjo et al. 2001.

Pendidikan - Promosi Dan Perilaku

Kesehatan (Teori dan Aplikasi)

$K M P$ - 600. Jakarta: FKM - UI.

Notoatmodjo, Soekidjo. 2003. Ilmu Kesehatan Masyarakat - Prinsipprinsip Dasar. Cetakan kedua. Jakarta: Rineka Cipta

Robbins, Stephen P. 2003. Perilaku Organisasi. Jilid I. Alih bahasa: Tim Indeks. Jakarta: PT Indeks kelompok Gramedia.

Syafrudin dkk. 2009. Ilmu Kesehatan Masyarakat Untuk Mahasiswa Kebidanan. Cetakan pertama. Jakarta: Trans Info Media.

Wiknjosastro, Hanifa. 1999. Ilmu Kebidanan. Edisi Ketiga. Cetakan Kelima. Jakarta: Yayasan Bina Pustaka Sarwono Prawirohardjo. 